$S_{F}$ 值は1のまわりにばらつく。ひん度分布の平均值 は $S_{F}=0.93$ の際存在する。すな的ち安全側である。 設計の際 $S_{F}=1.5$ を維持すれば計算のばらつき範囲 はおおわれる。

[大沢 水澄]

\subsection{3-752:678.077}

[384]ポリアミド霜車，実務経験［G. Alicke. Antriebstechn., 1971-6, Jg. 10, Nr. 6, S. 221 228, 図 18, 表 1] ポリアミドの対数減衰率は $60^{\circ} \mathrm{C}$ のとき, はがねより50〜100 倍も大きい。はが㸚とポリアミド 歯車の騒音测定で，音圧レベルは，はがねのほうが8 〜10 dB 大きいことを示した，歯元温度 度 $\vartheta_{F}$ は

$$
\vartheta_{z, F}=\vartheta_{a}+P \mu \frac{100(i+1)}{z_{1}+5 i}\left[\frac{17100 K_{2}}{b z\left(V_{m}\right)^{0.75}}+6.3 \frac{K_{3}}{A}\right]
$$

$\vartheta_{a}$ : 周囲温度 ${ }^{\circ} \mathrm{C}, P: \mathrm{PS}, \mu$ : 乾燥時 $0.2 \sim 0.3,1$ 回 グリース潤滑時 $0.09 \sim 0.12$, 油潤滑時 $0.04, i$ : 変速比 $z_{1} / z_{2}, z_{1}$ : 小画車数, $z$ : 計算対象歯数, $b$ : 歯幅 $\mathrm{mm}$, $V:$ 周速度 $\mathrm{m} / \mathrm{s}, K_{2}$ : 材質組合せ係数, $K_{3}$ : 開放歯車 か密閉歯車かによる倸数， $A$ : 歯車箱の表面積 $\mathrm{m}^{2}$.

ポリアミドの使用経験 12 例があげられる.3 例とし て，i）処方ひょう用ウォームギヤの歯車に用い, 給油 のためのほこりとの混合による金剛砂ペーストの発生 を防ぎ，寿命を数倍伸ばした。 ii）ポリエチレンはく による袋溶接機の駆動は，作業員への障害となる騒音 を避けるため，はが䅦車をポリアミドに変え 4 年以 来故障なくか衝している。iii）給油ポンプの駆動歯車 の1はポリアミド製で調質鋼歯車とかみあい, 1969 年 1 月以来毎月 $24 \mathrm{~h}$ の連続作業で，これまで $17000 \mathrm{~h}$ に達した。

[大沢 水澄]

\section{$621.876: 624.04$}

[385]エレベータの軸とピンの計算 [W. Dannenberg, Techn. Utberwach., 1971-5, Jg. 12, Nr. 5, S. 151〜153, 図 4, 表 1] エレベータにおける安全率は Niemannにより与えられた方法を適用すれば 1.5 で 十分としている. Niemannによる寸法効果倸数は切 久き軸にも適用できると仮定する。本来は平滑軸にの み有効であるのだが, 荷重の誤差, 衝撃, 加速度, 施 設の効率（走行抵抗，ケージカウンタウェイト）, 計 算の不正確をおおう係数として 1.13 とする.よって 安全率は $s=1.5 \times 1.13=1.7(200 \mathrm{~mm}$ 直径まで). 3 点支持の軸はエレベータにたいてい現われるが，モー ルによる理論的に正確な方法は非常に手間がかかる。 他方比較的ひんぱんな破断箇所として，中閒軸受にお ける曲げモーメントは 2 点のみの仮定では不可能だ。

そこで簡単な計算過程を選ぶ。これは全長等断面軸の 場合有効で十分正確な結果を導く（図 47）．曲げとね じりモーメントの合成は $M_{i}=\sqrt{ } \overline{M_{b}^{2}+0.75 M_{t}^{2}}$

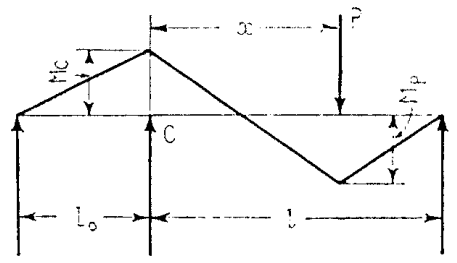

図 47 [大沢 水澄]

\section{$532.516: 621.891$}

[386] 境界潤滑の数学的モデルに関する批判的展望 [A. Beerbower, ASLE Trans., 1971-4, Vol. 14, No. 2, p. 90〜104, 図 6, 表 7] 境界潤滑状態における金 属の摩耗を，数学的なモデルをむとにして定量的に敃 おうという試みは，これまでにも数多くなされてい る。本稿はそれらの中から，疲れの概念取入れて奏 用的な摩耗式を提案した Bayer のモデル，摩擦面の潤 滑膜による被覆率を考慮して Archard の式を修正し た Rowe のモデル，腐食摩耗を取扱ったTaoのモデ ルを中心として吟味し，そのおのおのが境界潤滑の 分野において，摩耗が全く抽らないか，あるいはご く微量に生ずる領域にあてはまることを述べ，さらに 工業上好ましからざるような摩耗の生ずるか否かの判 定基準として用いうることを示㖫している。またこの ほか，潤滑㧩中の添加物と金属との反応や“friction polymer" の概念など，非可逆反応を考慮した場合の 摩耗の定量的取扱いにも触れており，現在は困難であ るが近い将来にその研究が必要であることを述べてい る.

$$
\text { [木村 好次] }
$$

\subsection{6 : $539.538: 620.178 .16$}

[387]金属面に対する重合物の摩耗［S.K. Rhee, Wear, 1970-12, Vol. 16, No. 6, p. 431 445, 図 18, 表 6]金属面に対する重合物の摩耗機構としてアブ レジョン, 熱的摩耗, 粘着, 巨視的せん断, 疲れなどが あげられる。そしてこの中の一つあるいは組合せによ って材料は摩耗するが, たとえば荷重, 速度, 時間な ど条件によってこれらの機構が影響をうけるのは当然 であり，そのために摩耗量を推定するのは一般にきう めて困難であって，したがって摩耗の満足な一般式は 現存しないのが現状である．Lewis はそれぞれ摩耗容 積を $v$, 荷重 $F$, 速度 $V$, 時間 $t$, 摩耗係数 $K$ として $v=K F \quad V t$ なる式を発表しているが著者らの実験結 果には適合しなかった。 そこで摩耗重量 $\Delta W, a, b, c$ をパラメータとして次式を提案し，いろいろの試験条 件や材料について実験的に検討している。

$$
\Delta W=K F^{a} V^{b} t^{c}
$$

実験の結果は上式によく一致し，試験条件によって パラメータ $a, b, c$ が定まる。また $K$ は条件がきまれ 壮実際上定数であることもかかった，なお重合物一重 合物，金属一金属，あるいはセラミック一金属の組合せ についても上式が適用されうるむのと思われるので， それらの研究が待たれると述心゙られている。

[恒川義徳]

\section{1-762.8}

[388] 弾性的に支持されたメカニカルシールの離間

[C.F. Zorowski and H.H. Hill, ASLE Trans., 19711, Vol. 14, No. 1, p. 73〜80, 図 8] メカニカルシー ルには一般にしゅう動面における接触面圧を与えるた めに、ばねが使用されている。ばねによって弾性的に 支持されているメカニカルシールでは回転軸の軸方向 振動，ウォーブリングにより密封性能が影響される が，本論文は軸振動に対するしゅう動面の追随を理論 的に解析したすのである. シール面の X, Y, Z 軸方向 に対する運動をオイラーの運動方程式よりもとめ, ア ナログ計算により追随におよぼす諸因子の影嵬をもと めている。 